\title{
The Connection Between Culture And Organizational Behavior
}

Sonja Treven, (E-mail: Sonja.treven@uni-mb.sl), University of Maribor, Slovenia

\begin{abstract}
The paper presents various approaches to studying cultures of different countries. The starting point is the Hofstede's dimensions of cultural values as well as Hall's approach to high-and lowcontext cultures and Trompenaars model of cultural differences. After that the interaction between culture and organizational behaviuor is discussed. A special attention to the impact of culture on motivation of employees, communication, conflict resolution and organizational changes is given.
\end{abstract}

\section{INTRODUCTION}

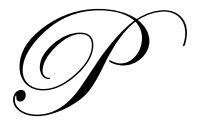

eople from different countries as well as regions inside them often do things in different ways. One way to explain variations in behavior is the idea of culture.

We cannot use a single definition of culture because the concept is complex. Hence, let us look at some definitions devised by different authors decades ago, up to the modern ones. Tylor (1871), for example, proposed one of the earliest definitions of culture. According to him, culture is »a complex whole which includes knowledge, belief, art, morals, law, custom, and any other capabilities and habits acquired by man as a member of society.« Herskowits conceived a little wider definition of culture more than four decades ago by suggesting that culture was a »humanmade part of the environment « (Herskowits, 1955). Trying to interpret his definition, we may talk about »objective culture« (e.g., tables, computers, trains) and »subjective culture« (e.g., norms, roles, values).

Let us mention some more definitions of culture that ensued after 1980. According to Hofstede (1991), culture is the software of the mind, similar to a computer program that controls behavior. On the other hand Lipičnik (1998) believes that »culture can not readily be expressed directly, for example, as a rule or pattern of behavior, but indirectly in our functioning and our relations to ourselves as well as to the environment - human beings, nature...."

Although more than 160 definitions of culture exist (Kroeber and Kluckhohn, 1985), the sample presented illustrate the variety of manifestations culture can take, both as a communicator and receptor of values. It is important to recognize that intra-cultural variation is ubiqutuous ( $\mathrm{Au}, 1999$; Alvesson, 2002), and that cultural variation exists in regions, organizations, and even individuals over time. Still, a large body of research suggests that meaningful, relatively long-lasting distinctions among various international cultures exist.

In this paper we will present a sampling of approaches to the study of culture. Then we will turn our attention to the interaction of culture and organizational behavior. We will present the effect of culture upon the motivation of employees, and its impact upon communication, the successful resolution of conflict, and organizational change.

\section{APROACHES TO THE STUDY OF CULTURE}

Researchers have developed various frameworks to classify the cultures of the world (cf. Darlington, 1996 for a review). Their models suggest what the approximate values of people in a particular culture will be. But they cannot predict what any one individual's constillation of values will be- not everyone in a particular culture believes or behaves in the same way. Sometimes, there is greater variation within single cultures than across cultures. 


\section{Hofstede's Definition Of Culture}

Hofstede specifically focused his attention on work related values in his study of culture. He collected data from IBM employees from 40 countries. In analyzing the data from more than 116,000 employees, Hofstede extracted four dimensions of values to explain the differences among cultures and then later added a fifth. Although his data was collected in the 1970s, several recent studies and data from outside Europe, have generally confirmed Hofstede's findings, with minor additions or differences (Chinese Culture Connection, 1987; Darlington, 1996; Hoppe, 1990; Smith, 1996; Trompenaars, 1993). Some substantial differences have also been cited when alternate methods are used or some non-European cultures are surveyed (e.g., Pearce and Osmond, 1999).

According to Hofstede $(1980,1991)$ cultures can be compared and classified on the basis of five different dimensions that affect behavior, organization practices, and social practices such as marriages, funerals, and religious ceremonies:

$\begin{array}{ll}\text { - } & \text { Individualism - collectivism } \\ \text { - } & \text { Power distance } \\ \text { - } & \text { Uncertainty avoidance } \\ \text { - } & \text { Short term - long term orientation }\end{array}$

The first dimension refers to whether individual or collective action is the preferred way to deal with issues. In cultures oriented toward individualism - such as the USA, the UK, and Slovenia - people tend to emphasize their individual needs and concerns and interests over those of their group or organization. The oposite is true in countries which score high on collectivism, such as, Asian countries such as Japan and Taiwan. In a collectivistic society, one is expected to interact with members of one's group. It is almost impossible to perceive a person as an individual rather than one whose identity comes from groups with which that individual is associated (Brislin 1993).

The second dimension - power distance-is connected er distance-is connected with the differences in power and status that are accepted in a culture (Zenko, 1999). Some nations accept high differences in power and authority between members of different social classes or occupational levels while other nations do not. For example, the French are relatively high in power distance; Israel and Sweden score very low. In Israel and Sweden, worker groups demand and have a great deal of power over work assignments and conditions of work (Adler, 1991). French managers tend not to interact socially with subordinates and do not expect to negotiate work assignments with them. Table 1 shows a sample grouping of countries based on individualism-collectivism and power distance.

Table 1: Sample Country Clusters On Hofstede's Dimensions Of Individualism-Collectivism And Power Distance (Schermerhorn, Hunt, Osborn, 2000)

\begin{tabular}{|l|l|l|}
\hline Collectivism & & $\begin{array}{l}\text { Colombia, Peru, Thailand, Singapore, } \\
\text { Greece, Mexico, Turkey, Japan, } \\
\text { Indonesia }\end{array}$ \\
\hline Individualism & $\begin{array}{l}\text { Israel, Finland, Germany, Ireland, New } \\
\text { Zeland, Canada, Great Britain, United } \\
\text { States }\end{array}$ & $\begin{array}{l}\text { Spain, South Africa, France, Italy, } \\
\text { Belgium }\end{array}$ \\
\hline
\end{tabular}

$\begin{array}{ll}\text { Low Power } & \text { High Power } \\ \text { Distance } & \text { Distance }\end{array}$

The third dimension, uncertainty avoidance refers to a relationship of a particular culture to the uncertainty characteristic of the future. Societies high in uncertainty avoidance tend to prefer rules and operate in seemingly predictable situations as opposed to situatiuons where the appropriate behaviors are not specified in advance. Those with high uncertainty avoidance prefer stable jobs, a secure life, avoidance of conflict, and have lower tolerance for 
deviant persons and ideas. Japan scores higher than the USA on uncertainty avoidance while both score higher than Sweden. This means that, for instance, in Japan there is far less tolerance for deviations from accepted behavioral practices than in the USA, while Sweden is generally considered to be a very tolerant society (Tosi, Mero, Rizzo, 2000).

The masculinity-femininity dimension of a culture refers to the degree to which values associated with stereotypes of masculinity (such as aggressiveness and dominance) and femininity (such as compassion, emphaty, and emotional openess) are emphasized. High masculinity cultures such as Japan, Germany, and the USA tend to have more sex-differentiated occupational structures with certain jobs almost entirely assigned to women and others to men. There is also a stronger emphasis on achievement, growth, and challenge in jobs (Hofstede, 1991). In these cultures, people are also more assertive and show less concern for individual needs and feelings, a higher concern for job perfomance and a lower concern for the quality of the working environment. In countries high on the feminine dimension such as Sweden and Norway, working conditions, job satisfaction, and employee participation are emphasized.

The very last among mentioned dimensions stem from the philosophy of the Far East and was added by Hofstede following the findings of the Chinese Culture Connection (1987). This dimension reflects a culture's view about the future. The short-term orientation, a western cultural characteristic, reflects values toward the present, perhaps even the past, and a concern for fulfilling social obligations. Long-term thought patterns, characteristic of Asian countries, reflect an orientation toward the future, belief in thrift and savings, and persistance. In countries with a long-term orientation, planning has a longer time horizon. Companies are willing to make substantial investments in employee training and development, there will be longer-term job security and promotions will come slowly.

\section{Hall's Cultural Model}

An American anthropologist Edward T. Hall used the concept of context to explain differences in communication styles among cultures. According to Hall, the context is $»$ the information that surrounds an event; it is inextricably bound up with the meaning of that event (Hall and Hall, 1995). He categorized cultures on a scale from high- to low-context. The examples of countries with a high- or low context communication style are presented in Table 2.

Table 2: Countries With A High- Or Low-Context Communication Style

\begin{tabular}{|l|l|}
\hline High-contex communication style & China, Egypt, India, Japan, Lebanon, Spain, Italy \\
\hline Low-context communication style & Australia, United States, Sweden, Switzerland, Germany \\
\hline
\end{tabular}

In a high-context culture it is characteristic that most of the information is either in the physical context or internalized in the person, while very little is in the coded, explicit, transmitted part of the message. In Saudi Arabia, for example, family, friends, coworkers, and clients have close personal relationships and large information networks. Because of this, people in high-context cultures know a lot about others within their networks. They do not require extensive background information. In these cultures, people do not rely on language alone for communication. Tone of voice, timing, facial expression, and behaving in ways considered acceptable in the society are oft used tools for communicating messages.

In low-context cultures the mass of the information is vested in the explicit code. People in Switzerland, for example, separate their lives into different aspects such as work and personal lives. Therefore, when interacting with others, they need to receive more detailed information. These cultures depend on the use of words to convey meaning. Expressing complete, accurate meaning through appropriate word choice is important. 


\section{Trompenaars' Dimensions Of Culture}

A framework developed by Fons Trompenaars offers a useful vantage point for better understanding and dealing with cultural differences. Working from a databank of respondents from 47 national cultures, he suggests that cultures vary in the way their members solve problems of three major types: (1) relationships with people, (2) attitudes toward time, and (3) attitudes toward the environment.

Trompenaars identifies five major cultural differences in how people handle relationships with other people. The orientations, as illustrated in Table 3, are:

1. Universalism versus particularism: relative emphasis on rules and consistency, or relationships and flexibility.

2. Individualism versus collectivism: relative emphasis on individual freedom and responsibility, or group interests and consensus.

3. Neutral versus affective: relative emphasis on on objectivity and detachment, or emotion and expressed feelings.

4. Specific versus diffuse: relative emphasis on focused and narrow involvement, or involvement with the whole person.

5. Achievement versus prescription: relative emphasis on performance-based and earned status, or ascribed status.

With regard to problems based on attitudes toward time, Trompenaars distinguishes between cultures with sequential versus synchronic orientations. Time in a sequential view is a passing series of events, in a synchronic view, it consists of an interrelated past, present, and future.

Table 3: Sample Country Clusters On Trompenaars' Framework For Understanding Cultural Differencies (Schermerhorn, Hunt, Osborn, 2000)

\begin{tabular}{|l|l|l|}
\hline Canada, USA, Ireland & Universalism vs. Particularism & Indonesia, China, Venezuela \\
\hline USA, Hungary, Russia & Individualism vs. Collectivism & Thailand, Japan, Mexico \\
\hline Indonesia, Germany, Japan & Neutral vs. Affective & Italy, France, USA \\
\hline Spain, Poland, USA & Specific vs. Diffuse & India, Great Britain, Egypt \\
\hline Australia, Canada, Norway & Achievement vs. Ascription & Phillipines, Pakistan, Brazil \\
\hline Great Britain, Belgium, USA & Sequential vs. Synchronic & Malaysia, Venezuela, France \\
\hline
\end{tabular}

With regard to problems based on attitudes toward the environment, he contrasts how different cultures may relate to nature in inner-directed versus outer-directed ways. Members of an inner-directed culture tend to view themselves separate from nature and believe they can control it. Those in outer-directed culture view themselves as part of nature and believe they must go along with it.

\section{THE IMPACT OF CULTURE ON ORGANIZATIONAL BEHAVIOR}

As communication technologies advance and countries become more closely linked through trade, more information about other cultures becomes available. Products are sold worldwide and in some cases marketed in the same way everywhere (Vecchio, 2000).

In Slovenia, as well as in other countries in the world, we can find someone eating a McDonald's hamburger while dressed in Levis jeans, sitting in a Honda filled with Shell gasoline. Because of this, some might say that cultures are becoming more alike and that the study of culture is therefore irrelevant. However, a closer look at what seem to be cultural universals reveal many differences. Having a McDonald's hamburger in Moscow or Beijing is somewhat trendy and the cost is well above average. In Washington, DC, eating at McDonald's is a mere convenience as well as one of the cheapest meals available. 
On another level, the effect of cultural differences can be clearly seen. Ethnic conflicts continue to flare around the world. These conflicts often result from attempts to maintain distinct cultural identities. Culture, although not the only variable of importance, contributes significantly to explaining key differences in societal behavior. With an appreciation of the role of culture in organizations comes a better understanding of management and organizational behavior around the world.

\section{Differences In Cultures And Motivation}

The culture of a country or region in which the organizations function influences the way of motivating employees a great deal. In collective countries, such as Japan, giving an individual reward to an employee could embarrass the recipient and thus be demotivating. In high-context collective cultures there are often expected norms of behavior for particular situations. Offering rewards for individual behavior that runs counter to group norms is unlikely to have a positive influence on motivation.

Hofstede's masculinity versus femininity dimension also suggests what could be rewarding for different societies. If a culture is masculine, people prefer to receive money, titles, or other materialistic or status-oriented rewards. In a feminine society, meaningful rewards are time off, improved benefits, or symbolic rewards.

In some countries, the perception of material items is as gifts rather than as rewards for performance. In China for example, organizations often distribute food to all employees as holiday gifts. People in higher positions get more or better quality items, but employees make no connection between their performance and the gifts (Tosi, Mero, 2003).

An important motivational factor for employees in all cultures is the meaning of work. In Table 4 the importance of different work goals in seven countries is presented. Rank 1 is the most important work goal for a country and rank 11 is the least important rank. Interesting work is the most important for employees in Britain, Belgium, Istrael and United States. Good pay is the most important for employees in Germany while a good match between the person and the job is the most important for Japans. Good physical working conditions is the least important factor for almost all countries.

Factors that motivate employees in organizations do not diverge only as regards cultures, but differ quite often within the particular culture. Which rewards are cherished by employees in Slovenia or Croatia does not only reflect the culture of Slovenes or Croats but also depends on other factors, such as age, gender, education, organizational level and tenure of the employees.

\section{The Effect Of The Culture On Communication Process}

People must always exercise caution when they are involved in cross-cultural communication - whether between persons of different geographical or ethnic groupings within one country, or between persons of different national cultures. A common problem is ethnocentrism as the tendency to believe one's culture and its values are superior to those of others. It is often accompanied by an unwillingness to try to understand alternative points of view and to take the values they represent seriously. This mindset can easily create communication problems among people of diverse background.

People in different cultures communicate among themselves differently. The major differences in how people from different cultures communicate with each other are language usage, verbal style, and nonverbal communication.

Two people may speak the same language but speak it quite differently. For example, people from the United States and England both speak English, but the meaning of certain words is quite different, sometimes even opposite, in the two countries. 
Table 4: Importance of Work Goals (Francesco, Gold, 1998)

\begin{tabular}{|c|c|c|c|c|c|c|c|}
\hline Work goals & Britain & Belgium & Germany & Israel & Japan & $\begin{array}{c}\text { Netherland } \\
\text { S }\end{array}$ & $\begin{array}{l}\text { United } \\
\text { States }\end{array}$ \\
\hline Interesting work & 1 & 1 & 3 & 1 & 2 & 2 & 1 \\
\hline Good pay & 2 & 2 & 1 & 3 & 5 & 5 & 2 \\
\hline $\begin{array}{l}\text { Good interpersonal } \\
\text { relations }\end{array}$ & 4 & 5 & 4 & 2 & 6 & 7 & 7 \\
\hline Good job security & 3 & 3 & 2 & 10 & 4 & 3 & 3 \\
\hline $\begin{array}{l}\text { A good match } \\
\text { between you and } \\
\text { your job }\end{array}$ & 6 & 8 & 5 & 6 & 1 & 4 & 4 \\
\hline A lot of authonomy & 10 & 4 & 8 & 4 & 3 & 8 & 8 \\
\hline Opportunity to learn & 8 & 7 & 9 & 5 & 7 & 5 & 5 \\
\hline A lot of variety & 7 & 6 & 6 & 11 & 9 & 6 & 6 \\
\hline $\begin{array}{l}\text { Convenient work } \\
\text { hours }\end{array}$ & 5 & 9 & 6 & 7 & 8 & 9 & 9 \\
\hline $\begin{array}{l}\text { Good physical } \\
\text { working conditions }\end{array}$ & 9 & 11 & 11 & 9 & 10 & 11 & 11 \\
\hline $\begin{array}{l}\text { Good opportunity } \\
\text { for promotion }\end{array}$ & 11 & 10 & 10 & 8 & 11 & 10 & 10 \\
\hline
\end{tabular}

Verbal communication styles are another way for cultures to vary in their communication patterns. In cultures employing a direct style the speaker tries to convey his true feelings through the choice of words. In the indirect style, the speaker selects words to hide his real feelings. For example, North Americans using the direct style say, »No« or »I can't do that « if they are unable to make a particular deal. In contrast, a Korean speaker might say, »It might be possible«, or »It's interesting in principle«, rather say »no« directly. The direct style is common in individualistic, low-context cultures, and the indirect style in collective, high-context cultures. The direct style allows the individualist to express his own ideas clearly. The collectivistic orientation is to maintain group harmony and concern for the feelings of others.

Culture also has quite a strong impact on nonverbal communication which may be expressed through facial expression, gestures, eye contact and posture. For example, the smile usually indicates happiness or pleasure, but for Asians, it can also be a sign of embarrassment or discomfort (Samovar, Porter, 1991; Hellriegel, Slocum, 2004). The level of gesturing in Italy, Greece, and certain Latin American countries is so high that people appear to be speaking with their hands. For Chinese and Japanese speakers, using gestures is less common. Greeting gestures also differ. In a business situation, North Americans shake hands, Japanese bow, and Middle Easterners of the same sex kiss on the cheek (Abbasi and Holman, 1993).

\section{The Impact Of Culture On Conflict Resolution}

The way people sense conflicts varies widely with culture. Intercultural communications expert Stella TingToomey has developed a theory of culture and conflict that explains cultural differences using Hall's low-and highcontext framework (Gundykunst and Ting-Toomey, 1988; Hall, 1976; Hall, Hall, 1995).

According to this theory people in low-context cultures see conflict as instrumentally oriented. These cultures view the world in analytic, linear logic terms, and separate issues from people. Public disagreements are acceptable, people can have a conflict and still maintain a friendly relationship afterwards. In a high-context culture, conflict is expressive oriented. People in these cultures do not separate person from issue. Open disagreement and public confrontation are highly insulting and cause both parties involved to »lose face «.

In either type of culture, conflicts develop for different reasons. In low-context cultures there is less specification of appropriate ways to behave. Conflict often arises because one party violates the other's expectations. 
In the high-context culture, which has more specific rules of behavior, conflict usually occurs when a person violates cultural expectations.

The third aspect of the conflict situation refers to the behavior of people involved in the conflict. In the lowcontext culture, people are oriented toward action. This results in a direct, confrontational response to conflict, with all parties wanting a quick resolution. In the high-context setting, the attitude toward conflict is evasive and nonconfrontational, leading to an indirect, inactive approach. This often results in avoiding or ignoring the conflict.

Among the popular dimensions of culture in Hofstede's model discussed in previous Chapter, substantial differences may be noted in time orientation. When persons from short-term cultures such as the United States try to work with persons from long-term cultures such as Japan, the likelihood of conflict developing is high.

The same holds true when individualists work with collectivists and when person from high-power distance work with those from low-power distance cultures (Schermerhorn, Hunt, Osborn, 2000). In each case, individuals who are not able to recognize and respect the impact of culture on behavior may contribute to the emergence of dysfunctional situations. On the other hand, by approaching a cross-cultural work situation with sensitivity and respect, one can find ways to work together without great difficulty and even with the advantages that constructive conflict may offer (Robbins, 1998).

\section{National Culture And Organizational Change}

Cultures vary in their receptivity to change. Some cultures change slowly and actively resist change - even to the point of attempting to prevent outside influences - because they value traditional behavior. Other cultures embrace change but, on occasion, significant segments of their population attempt to reestablish traditional values and behavior and view progress as a threat. Yet other cultures are ambivalent toward change and simultaneously embrace, resist, and fear it (Treven, 2001).

One way to understand a culture's relationship to change is its orientation toward time (Trompenaars, 1993). Some cultures are past oriented, view tradition and history as important, and interpret the present through the lens of ancient principles, customs, and texts. Other cultures are present oriented and focus on the moment. For these societies, history is relatively unimportant and the future is not of great concern. Finally, some cultures are future oriented and emphasize planning and future achievements. In these societies, progress is a central theme, the fate of future generations is a concern, and there is belief that rational thought can guide human action. Traditional cultures with a past orientation resist change, whereas cultures with a present-orientation display either ambivalence or reluctant acceptance of the new. Cultures with a future orientation tend to view change as desirable and, to some extent, inevitable (Treven, 2003).

Even present, and future-oriented societies experience resistance to change. To some extent, for all cultures, resistance to change is attributable to the uncertainty associated with change, including the awareness that change is not always improvement and can produce unintended consequences or reverse results with negative outcomes. It is important for managers to understand sources of resistance to change so they can anticipate and reduce them. Tradition, habit, resource limitations, threats to power and influence, and fear of the unknown, are forms of resistance to change found in all societies.

\section{CONCLUSION}

In a modern, increasingly interdependent world, studying culture is essential for managers. They have to think globally, notwithstanding the country they live in. No matter what their company produces or to what market it sells the products it will encounter global competition everywhere. Even in the small nation of Slovenia, which has a lot of companies that successfully meet the needs of people for various products and services, we can observe an ever increasing occurance of foreign competition on the domestic market. As recently as 2000, for example, companies from abroad, such as OBI, Baumax and Intespar built three modern shopping centers in Maribor, the second biggest town in Slovenia. 
It is important for managers to study other cultures also because their competitors, suppliers, shareholders, or employees may come from other cultures. In developed countries - of which Slovenia would be one -- there are also an increasing number of immigrants and guest workers bringing their own cultures into their new homes. Managers have to be able to integrate them into the new work environment. Hence, it is necessary for managers to know their culture as well as to understand their way of life.

\section{REFERENCES}

1. $\quad$ Alvesson, M. (2002). Understanding Organizational Culture. Sage Publications, London.

2. Abbasi, S.M. and K.W. Hollman. (1993). Business Success in the Middle East, in: Management Decision, 31(1): 55-59.

3. Adler, N.J. (1991). International Dimensions of Organizational Behavior, PWS-KENT, Boston.

4. Au, K.Y. (1999). Intra-Cultural Variation: Evidence and Implications for International Business, in: Journal of International Business Studies, 30: 799-812.

5. Brislin, R. (1993). Understanding Culture's Influence on Behavior, Harcourt Brace Jovanovich, Fort Worth.

6. Chinese Culture Connection, Chinese Values and the Search for Culture-Free Dimensions of Culture, in: Journal of Cross-Cultural Psychology, (1987) 18: 143-164.

7. Darlington, G. (1996). Culture: A Theoretical Review, in: P. Joynt and M. Warner (eds.), Managing Across Cultures, International Thomson Business Press, London.

8. Gunykunst, W.B. and S. Ting-Toomey. (1988). Culture and Interpersonal Communication, Sage, Newbury Park, California.

9. Hall, E.T. (1976). Beyond Culture, Anchor Press, Garden City, New York.

10. Hall, E.T. and M.R. Hall. (1995). Key Concepts: Underlying Structures of Culture, in: H.W. Lane, J.J. Di Stefano and M.L. Maznevski: International Management Behavior, Blackwell Publishers, Cambridge, Massachusetts.

11. Hampden-Turner, C. (1994). Corporate Culture: From Vicious to Virtuous Circles, Piatkus, London.

12. Hellriegel D. and Slocum, Jr., J.W. (2004). Organizational Behavior. Thomson South-Western, Mason, Ohio.

13. Herskovits, H.J. (1955). Cultural Anthropology, Knopf, New York.

14. Hofstede, G. (1980). Culture's Consequence, Sage, Newbury Park, California.

15. Hofstede, G. (1991). Cultures and Organizations, McGraw-Hill, London.

16. Hoppe, M.H. (1990). A Comparative Study of Country Elites: International Differences in Work-Related Values and Learning and their Implications for Management Training and Develoment, unpublished PhD thesis, University of North Carolina at Chapel Hill.

17. Kroeber, A. and C. Kluckhohn. (1985). Culture: A Critical Review of Concepts and Definitions, Random House, New York.

18. Leeds, C. (1996). Pragmatic and Who list Approaches to Management in Emerging and Newly Emergent Democracies, in: P. Joynt and M. Warner, Managing Across Cultures, Thomson International Business Press, London.

19. Lipičnik, B. (1998). Ravnanje z ljudmi pri delu, Gospodarski vestnik, Ljubljana.

20. Pearce, C.L and C.P. Osmond. (1999). From Workplace Attitudes and Values to a Global Pattern of Nations: An Application of Latent Class Modeling, in: Journal of Management, 25: 759-778.

21. Robbins, S.P. (1998). Organizational Behavior, Prentice-Hall International, New Yersey.

22. Sathe, V. (1985). Culture and Related Corporate Realities, Irwin, New York.

23. Samovar, L.A. and R.E. Porter (1991). Communication Between Cultures, Wadsworth, Belmont, California.

24. Schermerhorn, J.R., Jr., Hunt, J.G., and R.N. Osborn (2000). Organizational Behavior, John Wiley \& Sons, New York.

25. Smith, P.B. (1996). National Cultures and the Values of Organizational Employees: Time for Another Look, in: P. Joynt and M. Warner (eds.), Managing Across Cultures, International Thomson Business Press, London.

26. Tosi, H.L. and N.P. Mero. (2003). The Fundamentals of Organizational Behavior. Blackwell Publishing, Oxford. 
27. Tosi, H.L., N.P. Mero, and J.R. Rizzo. (2000). Managing Organizational Behavior, Blackwell, Cambridge, Massachusetts.

28. Treven, S. (2001). Mednarodno organizacijsko vedenje, Gospodarski vestnik, Ljubljana.

29. Treven, S. (2003). The role of culture in organizations, in: Wilby, J. (ed.), Ellen, J.K. (ed.). Proceedings of the 47th Annual Conference of ISSS. July 7-11. Iraklion, Crete, Greece.

30. Treven, S. (2005). The connection between culture and organizational behavior. In: Program \& Proceedings, (ABR Conference proceedings, Puerto Vallarta, 2005). [Compact disc ed.]. [S.1.: s.n.], 9 pages.

31. Trompenaars, F. (1993). Riding the Waves of Culture: Understanding Diversity in Global Business, Irwin, New York.

32. Tylor, E. (1871). Origins of Culture, Harper and Row, New York.

33. Vecchio, R.P. (2000). Organizational Behavior. The Dryden Press, Forth Worth.

34. Zenko, Z. (1999). Comparative analysis of management models in Japan, United States of America, and Western Europe: doctoral dissertation, Ekonomsko-poslovna fakulteta, Maribor, Slovenia. 


\section{NOTES}

